DOI: https://doi.org/10.15276/hait.02.2021.1
UDC 004.942 + 621.923

\title{
COMPUTER-AIDED DESIGN AND PRODUCTION INFORMATION SUPPORT
}

\author{
Vasily P. Larshin ${ }^{1)}$ \\ ORCID: https://orcid.org/0000-0001-7536-3859; vasilylarshin@gmail.com \\ Natalia V. Lishchenko ${ }^{2)}$ \\ ORCID: https://orcid.org/0000-0002-4110-1321; odeslnv@ gmail.com \\ Olga B. Babiychuk ${ }^{1)}$ \\ ORCID: https://orcid.org/0000-0002-0623-265X; obbabiychuk@ukr.net \\ Ján Pitel ${ }^{3)}$ \\ ORCID: https://orcid.org/0000-0003-1942-0438; jan.pitel@tuke.sk \\ 1) Odessa National Polytechnic University, 1, Shevchenko Ave. Odesa, 65044, Ukraine \\ ${ }^{2)}$ Odessa National Academy of Food Technology, 112, Kanatna Str. Odesa, 65039, Ukraine \\ ${ }^{3)}$ Technical University of Kosice, 1, Bayerova. Prešov, 08001, Slovak Republic
}

\begin{abstract}
Information support for modern computer-aided design of products and processes is considered in this review in accordance with the methodology of the integrated CAD/CAM/CAE system. Three levels of the management hierarchy at the design and production stages are considered. At the top (organizational) level, computer-aided design of the product structure and its manufacturing technology is performed. At the middle (coordinating) level, a binding to existing technological equipment and debugging of individual fragments of the control program are performed. At the lower (executive) level, the control program is finally created, debugged and executed. A distinctive feature of the proposed automation methodology at the design and production stages is the use of feedback from the lower level to the middle and upper levels to correct the decisions made there, taking into account the existing management powers at these levels of the hierarchy. Thus, the indicated levels of the hierarchy of the intelligent system correspond to the hierarchy of objects and subjects of management and control, taking into account the powers (and capabilities) of management and control at each level. Information is a basic category not only in information (virtual) technology for its transformation and transmission, but also in physical technology of material production in the manufacture of a corresponding material product. Such technology as a rule, contain preparatory (pre-production) and executive (implementation) stages. At the preparatory stage, a virtual product is created (an information model of a real product in the form of virtual reality), and at the executive stage, a real (physical) product appears that has a use value (possession utility). This research describes the features of information processing at both stages of production in order to increase its efficiency.

Keywords: Information Technology; Automation; Product Design; Process Design; Digital Model; CAD/CAM/CAE; Control Program; Feedback; Metalworking Fluid; Sold Lubricant; Cutting Tool; Grinding System; Production Flows; Intelligent Control
\end{abstract}

For citation: Larshin V. P., Lishchenko N. V. Babiychuk O. B., Ján Pitel'. Computer-Aided Design and Production Information Support. Herald of Advanced Information Technology. 2021; Vol. 4 No. 2: 111-122. DOI: https://doi.org/10.15276/hait.02.2021.1

\section{INTRODUCTION}

The world economy is going through the fourth industrial revolution of its development [1]. A distinctive feature of this "Industry 4.0 " revolution is the widespread use of automation and computerization of technological processes and technological systems to ensure the efficiency of various industries and the so-called sustainable economic development. The role and significance of complex automation of production can hardly be overestimated when the risk of man-made disasters, climatic changes in the environment (global warming), pandemic (COVID-19), etc. In these conditions, com puter automation of production in mechanical engineering technology and other economic branches plays a

(c) Larshin V., Lishchenko N., Babiychuk O.,

Pitel’ Ján, 2021 paramount role for the world and domestic economy.

There are two definitions of the term "automation" for manufacturing processes and manufacturing systems. According to the first automation definition, manual labor and manual control is replaced by machine labor and machine control, respectively. According to the second automation definition, it is developing new manufacturing processes and manufacturing systems that cannot be implemented manually.

Mechanical engineering technology is a complex engineering and scientific discipline about the manufacture of machines of the required quality, in a given quantity, and at a given time, with the lowest labor intensity and cost of their manufacture. The production process of making machines and their elements includes a product design (computer-aided design or CAD), a process design (computer-aided

This is an open access article under the CC BY license (http://creativecommons.org/licenses/by/3.0) 
manufacturing or CAM), and production scheduling. The CAD and CAM allow significantly reducing production costs and are currently carried out within the integrated CAD/CAM/CAE system, the structure of which corresponds to the product design (CAD) and process design (CAM) stages in the product life cycle.

At the first stage (CAD), the product computeraided design is performed based on the product geometric digital 3D model. The result of this stage is an information geometric model of the product, which can be represented by a set of design documentation, to wit: working drawings of parts, assembly drawings of product structure, hydraulic, electrical, and other schemes.

At the second stage (CAM), computer-aided process design (planning) for product manufacturing (machining and assembling) is performed. The initial information for automated manufacturing process is the product information digital 3D model developed at the previous CAD stage. The result of the process design stage (CAM stage) is the automated preparation of $\mathrm{CNC}$ control programs based on the computer-aided programming system postprocessor. Thus, the created CNC control program results from of sequential actions along the CAD/CAM/CNC chain and indicates the end of the pre-production stage. This is the so-called open-loop control (i.e., without feedback) which is provided by $\mathrm{CAD} / \mathrm{CAM} / \mathrm{CNC}$ means and experienced technologists.

Obviously, with the technological systems' actual operation developed at the CAM stage (implementation stage), the process's basic parameters (state parameters and output parameters) will not equal the corresponding designed values. In this regard, an urgent task is to develop a methodology for correcting decisions made at the pre-production stage. One of the possible ways to solve this problem is the developing self-training technological (e.g., grinding) systems, which becomes possible when using such areas of automation as adaptive and intelligent control systems.

When automating design and production, it is necessary to take into account the available experimental data of this production, for example, the actual lubricating and cooling technological means. Technical lubricants (solid, liquid, gaseous) in engineering and technology are used in two main functional areas [2]. The first area is that when the lubricant is design material that ensures functioning machines and mechanisms at the stage of their operations (lubricants to decrease friction and wear). The second area is that when the lubricant is a necessary additional means for improving the machinability of machine parts by cutting and grinding of these parts at the stage of their manufacturing (lubricants for metal cutting and grinding).

The functional requirements for the lubricants are due to these two directions. In the first case, the lubricants should reduce friction and wear of parts during the machine's operation, and contribute to an increase in their durability. In the second case, the lubricants must be destructive in relation to the material being machined, i.e. they should facilitate the machining of these materials, and concurrently they should be stabilizing and resource-restorative in relation to the cutting tool. In both cases, these lubricants must be environmentally safe and comply with sanitary standards for their use.

This article focuses on such aspects of the performance properties of the lubricants which are not adequately reflected in the literature, namely on the features of the solid lubricants (hereinafter SL or SLs for single and plural, respectively) based on technical stearic and oleic fatty acids. Such SLs are environmentally friendly; they are cheaper in terms of the cost of their production and operation.

By comparative experimental study of both SLs and metalworking fluids (hereinafter MWF or MWFs), it is established that SL provides a lower coefficient of friction. In addition, SLs have the technological advantage when drilling small holes (diameter less than $5 \mathrm{~mm}$ ) without MWF (i.e. drilling fluid), particularly when drilling holes in parts of stainless steel.

The role of friction modifiers (molybdenum diselenide, sulfur, serpentinite) in increasing the lifecycle of drill bits made from tool steel, as well as in reducing torque and axial cutting force in drilling, under otherwise equal conditions, has been experimentally studied [2].

The effectiveness of SL for surface grinding workpieces of hardened steels in the combined use of the SL and conventional MWF is shown also [2]. In this case, the SL improves the machinability of the workpiece material in the grinding system, while the MWF cools the workpiece being ground to prevent its temperature defects.

Additional features of the research performed are the use of an electron microscope for drill bits chemical analysis and automated research computer system. This system includes the modern computer data acquisition device NI-DAQ ${ }_{m x}$ (hardware) with NI-LabVIEW (software) based on which the cutting monitoring and diagnosing computer subsystems can be developed for relevant CNC machines.

\section{ABSTRACT AND CONCRETE IN AUTOMATION}

This section discusses the sources of information related to the features of approaches and 
phenomena that need to be taken into account when automating design and production.

The last 40-50 years, without exaggeration, can be called the time of development of information industries. Information technology covers all areas of human activity, including politics, economics, industry, education, art and others [3]. To the present, manufacturing has been recognized as a skillful function which is implemented in a workshop. Manufacturing is no longer merely machining or fabrication. Moreover, manufacturing systems are covering everything from order receipt through the product shipment [4]. There is no need to assert (this is clear from the very beginning) that all the stages of developing an integrated manufacturing system (including $\mathrm{CAD} / \mathrm{CAM} / \mathrm{CAE}$ ) correspond to the product life cycle, on the one hand, and are based on information and its meaning depending on the stage, on the other hand. In this regard, great (and over time increasing) importance is attached to improving the efficiency of productive technologies based on virtual and physical technologies.

The development of virtual reality brings an old and historic question on the difference between the real world and unreal world. What we call "virtual reality" is a representation of an actual or nonactual world and the criterion of difference between the "real world" and "virtual reality" is whether we present it with the intention of using it as a representation. In other words, "virtual reality" is presented as a simulation or representation of an (actual or non-actual) world, whereas what we call the "real world" is not presented as such [5].

The observed information process, creating its "observer", connects reality, information, and the "observer". What do the observers actually observe? Do they observe reality? What is the information they observe? And how is the observed information connected with the reality of observation? What is the scientific path to uncovering the fact of reality through its observed information? All these questions are still unanswered in known publications [6].

The linguistic meaning of information includes issues of modeling and simulation [7], on the one hand, and issues of automation of technological processes and technological systems [8], on the other hand.

That is why this research deals with conception, principles, and procedures needed to explain both the essence of and the difference between two production flows, namely the flow of information and the flow of materials. The objective of research is to establish the necessary and sufficient conditions for ensuring the progress of an integrated manufacturing system in terms of efficient product design and manufacturing.
The tasks to be solved relate to two main directions. The first direction is to reveal a linguistic meaning of information in the kind of terms and concepts, ranging from artificial intelligence to education (see conclusion). The second direction is to establish how progress is ensured in production systems when manufacturing a product with information support for the stages of production and its preparation. To some extent, the second direction takes into account the peculiarities of distance learning $[9,10]$ when the physical (not virtual) process is the learning process itself [11].

As for the actual experimental data (mentioned above) the literature analysis allowed establishing two main classes of technical lubricants according to their functional application. The first lubricant class (nondestructive) represents the technical lubricant as a working construction material without which the work of the machine interacting parts is impossible. For example, the interaction of the bearing shell with the engine crankshaft is impossible without the introduction of oil into the contact area of these parts. The second lubricant class (destructive) represents the technical lubricants with the aid of which the materials machinability by cutting and grinding is greatly improved. Concurrently, the cutting forces and the temperature in the contact zone are reduced, and the cutting tool life is increased.

The first class of lubricants (nondestructive) is discussed in detail in the works $[12,13]$. In most tribological applications, liquid or grease (semisolid) lubricants are used to reduce friction and wear [14, 15]. Anti-wear additives and friction modifiers are added to them to increase the efficiency of these lubricants. These additives are active ingredients that can be added to base oils during the mixing process to enhance their existing characteristics or to add new properties that they lack. There are new trends in this class of lubricants, namely: anti-wear antifriction composition with natural materials of serpentine group [13].

Lubricants for metal cutting and grinding (liquid, grease, and solid) are working materials that affect the cutting and grinding system performances (operation quality). Besides, lowering the temperature in the cutting and grinding zone is also one of the main tasks [16, 17]. MWF is the conventional choice to act as both lubricant and coolant. There are some trends in this class of the lubricants which is related to limiting the MWFs use. The new technique of minimum quantity lubrication (MQL) is proposed to ensure reduced MWF flow [18, 19]. MQL uses the minimal quantity of MWF, which is jetted with high-pressure gas to the cutting or grinding zone [20]. 
Adding to MWF about $2 \%$ of the special means named as 'antifriction regenerative composition' (ARC) increases life of both the cutting tool and grinding wheel in 2-20 times [21]. The ARC is similar to anti-wear antifriction composition and also includes the serpentine substance. The similar mineral-containing additive reduced friction and wear, showing the opportunity to formulate the socalled energy saving lubricants [22]. At the same time, the use of MWFs is potentially dangerous (a source of pollution and work-related diseases) and expensively. Hence, there arises a need to identify eco-friendly and user-friendly alternatives to conventional cutting fluids [23]. Modern tribology has facilitated the use of SLs as an alternative to conventional MWFs in machining. For example, the benefits of SLs for cutting are noted in work [24] whose authors investigate the effect of the SLs with graphite and molybdenum disulphide on surface quality, cutting forces, and specific energy in end milling on the experimental setup for SL powder assisted machining. The fine SL powder, with $2 \mu \mathrm{m}$ average particle size, was loaded into the hopper of the feeder directly without any binder (base).

So, the machining process performance of SLs containing serpentinite have not been studied yet, while studies of liquid lubricants with serpentine substance have shown positive results with reduced friction and wear. The literature mentioned, as well as total reviews [25, 26], did not reflect the direction associated with the use of the metalworking SLs based on oleic and stearic fatty acids, including the use of serpentinite powder (more pure mineral than serpentine), with about $1 \mu \mathrm{m}$ average particle size, as one of the SL components both in drilling and grinding.

\section{TYPES OF AUTOMATED SYSTEMS}

In accordance with the general systems theory (systems engineering) one of the important initial stages of a system development is an adequate representation of the system from the concept stage to the running one. The system design includes its description, modelling and simulation, which may be represented in the respective formats: verbal description (text) in ordinary languages, graphical representations (block diagram, graphs), special signs systems (e.g., programming languages), mathematical model, a timing diagram, the combined method, etc. Selecting an appropriate way of the system representation depends on the purpose of the study. If the purpose is to create conditions to ensure the desired course of a process, when the process is the developing system, then it should be said of the system operation and control algorithms. In this case the technical system is being developed in the form of a con- trol system model. In this modelling (versus simulation) the system is a mathematical abstraction that is taken as a model of a dynamic phenomenon which represents the dynamic phenomenon in terms of mathematical relations. According to H. Freeman [27] such a system is characterized by the input $\boldsymbol{u}$, state $\boldsymbol{x}$ and output $\boldsymbol{y}$ (Fig. 1).

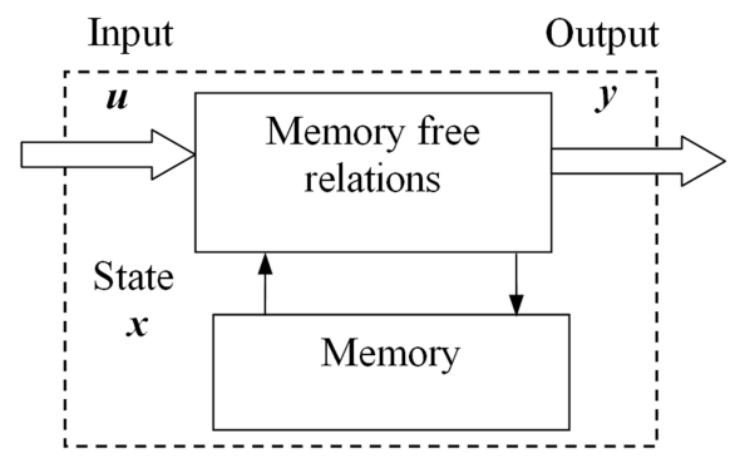

Fig. 1. Representation of the grinding system based on "input-state-output" model (a) [27] Source: [27]

The input $\boldsymbol{u}$ in the form of a set of time functions (e.g., in time domain) is the external forces (input variables) which are acting upon the grinding process that represents the dynamic phenomenon mentioned. The state $\boldsymbol{x}$ is a form of the system statespace representation, which with the input affects the output $\boldsymbol{y}$. The output $\boldsymbol{y}$ in similar form is the measures of the grinding process result, i.e. output quantities belonging to the ground part (part accuracy, surface finish and surface integrity).

A basic characteristic of any dynamic phenomenon is its behavior at any time and whether or not the behavior is traceable not only to the presently applied forces (input variables) but also to those applied in the past. A dynamic phenomenon (process) may or may not possess a memory depending on whether or not the effect of past applied forces is stored. In this connection the state $\boldsymbol{x}$ of the system is a vector function of time (e.g., in time domain) as well as both the input $\boldsymbol{u}$ and output $\boldsymbol{y}$. In grinding it may be corresponding signals like those of grinding forces $F$ in Newtons, temperature $T$ in Celsius or acoustic emission $(A E)$, e.g. in root mean square quantities.

Similarly, the system approach have been taken by H.K. Tönshoff et al [28] to explain a strategy of decision making while interpreting a process monitoring in grinding without (Fig. $2 a$ ) and with (Fig. $2 b$ ) a process model. There are two approaches for the decision making. Firstly, the distinctive values of the processed signals are to be compared with a predetermined threshold in order to identify the status of the grinding process by means of preparing 
a process database (memory stored). This approach is the preferred choice for sensor signals used to interpret output quantities. Secondly, a model based identification approach may be when various kinds of physical or empirical models are employed which utilize known relationships (Fig. $2 b$ ). As a result, the calculated value is compared with a threshold in order to evaluate the process. This approach is the preferred choice for the sensor signals used to monitor the process quantities which are equal to the system state ones. Because of its complexity and significance, the model based identification approach involves understanding the process model (don't confuse with the grinding system model). In this connection the methods for process modelling are of great impotence as they are in decision making.
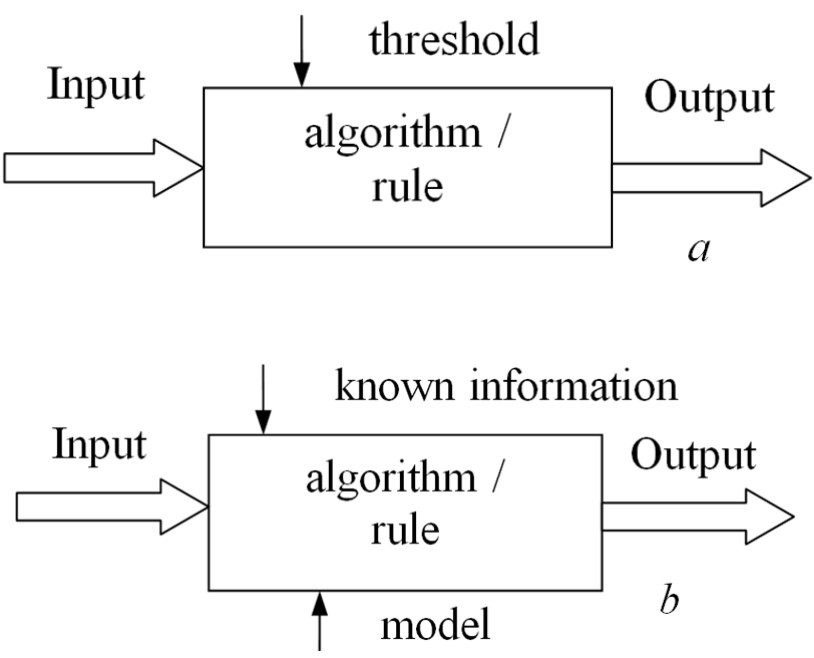

\section{Fig. 2. Representation of the grinding system based on "input-state-output" model for decision making without $(a)$ and with $(b)$ a model [28] Source: [28]}

Methods for process modeling discussed further. Besides the model definition mentioned above another term to explain 'model' may be as follows: a model is the abstract representation of a manufacturing process which serves to link causes and effects [28]. That is why the description of the correlation of different quantities of a real system to correspond to a modeled system is the dominant task of process models. In grinding, the dependences of settings on process quantities such as grinding forces $F$, temperature $T$, and acoustic emission $A E$ as well as on output quantities such as surface roughness and surface integrity (surface layer quality like grinding burns and residual stresses) may be mapped too on the basis of F. Klocke' representation [29]. Taking into account this representation, a model of technological grinding system can be represented as follows. The model consists of the following state parameters:
$Q^{\prime}{ }_{w}, V^{\prime}{ }_{w}, F, T, A E$, where $Q^{\prime}{ }_{w}$ is the specific material removal rate in $\mathrm{mm}^{3} /(\mathrm{s} \cdot \mathrm{mm}), V^{\prime}{ }_{w}$ is the specific material removal in $\mathrm{mm}^{3} / \mathrm{mm}$.

Questions of the theory of hierarchical intelligent control systems are considered in [30, 31], however, the material presented there is not tied directly to the automation of technological processes and systems at the stages of production and its preparation [32]. These issues are considered in more detail in [33, 34]. Besides, questions of the development of educational disciplines on automation, as well as questions on the technology of teaching in higher education institution are considered in [35]. Finally, the relationship between the virtual and the real in the automation of design and production is given in [36].

Let's introduce some definitions. Firstly, a process as a technical and technological system is a set of elements that are located in time, i.e., in a temporal sequence of ordered actions, e.g., the sequence of operations, operation steps, working passes, etc. Secondly, a technological system is a construction (space structure), i.e. not a process, that is assembled by a technologist for the technological process (operation) duration. This structure (as a technical system-construction) is a collection of elements that are located in space (machine, fixture, cutting tool, workpiece).

The modern understanding of $\mathrm{CAD} / \mathrm{CAM} / \mathrm{CAE}$ automation is considered taking into account the product life cycle [8], which contains a number of time stages, including product design $(\mathrm{CAD})$, process design $(\mathrm{CAM})$, and process systematic engineering calculations (CAE) with special computer software packages, as well as the product testing and the process assessing (Fig. 3).

At the CAD stage of the product life cycle the product design is performed with computer packages (Compass, Solid works, AutoCAD, Inventor, etc.). According to Fig. 2 optimization of the product constructive parameters is carried out using the constructive systematic engineering calculations (ANSIS, MATLAB, etc.) of CAE-system (construction).

At the CAM stage of the product life cycle, process design is performed with special computer packages (COMPASS Auto-project, Vertical, Mastercam, T-flex, etc.). According to Fig. 2 optimization of the process parameters is carried out using the constructive systematic engineering calculations (COMSOL Multiphysics, MathCAD, MATLAB, etc.) of CAE-system (technology). It makes it possible to justify the adopted technology from the product quality assurance point of view, for example, the thermal fields and thermal stresses calculations in grinding to predict grinding burns and microcracks, etc. 
At the post-processor stage (Fig. 3) a control program for $\mathrm{CNC}$ machine is prepared to control the machine at the production stage. This is the stage of actual implementation of work, for the sake of which all the previous stages of the product life cycle have been completed.

The diagram in Fig. 3 shows that the CAM system output is a control program for a CNC machine, which is generated by a post processor and fed to this machine, for example, the gear grinding CNC machine Höfler Rapid 1250. It is obvious that the technological parameters assumed at the prepreparation stage (gear grinding system state and output parameters) will not coincide with the actual ones of the operating grinding system. As follows from Fig. 3, it is not possible to bring these parameters to equality by making adjustments to the CAEsystem in automatic mode (without human intervention). However, it is possible to introduce a novel negative feedback, as well as new blocks and connections between them, as shown in Fig. 4. In this case, the actual on-line values of the gear grinding system parameters (state and output parameters) can be compared automatically with their calculated values that are available in the CAE-system and ob- tained either by analytical calculations or by online modeling in the appropriate FEM (finite element method) or FDM (finite difference method) system, e.g., in the FEM-system COMSOL Multiphysics.

\section{COLLATION OF EDUCATIONAL AND MANUFACTURING PROCESSES}

The problem follows from the following reasoning. The educational process in higher education institution (hereinafter university) is one of the most complex technological processes (with elements of intellectual control), the result of which is an unusual "product", namely the worldview and a set of special competences of the trained specialists. For the successful creation of such a "product", the corresponding hierarchical "control program" (with a large number of relevant subprograms, e.g., in the form of syllabuses) is compiled and continuously improved. Such "control program" is similar to the control program for CNC machines and is created on the stage of technological preparation of production, for example, by mechanical engineering technology specialists.

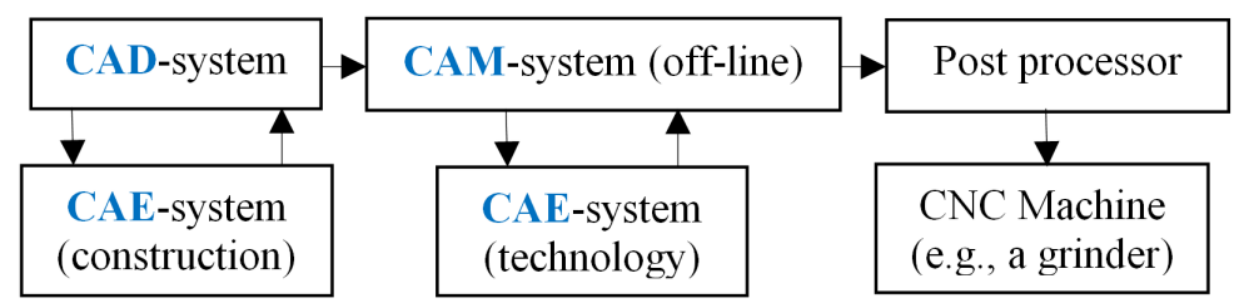

Fig. 3. Integrated system CAD/CAM/CAE in mechanical engineering technology Source: [36]

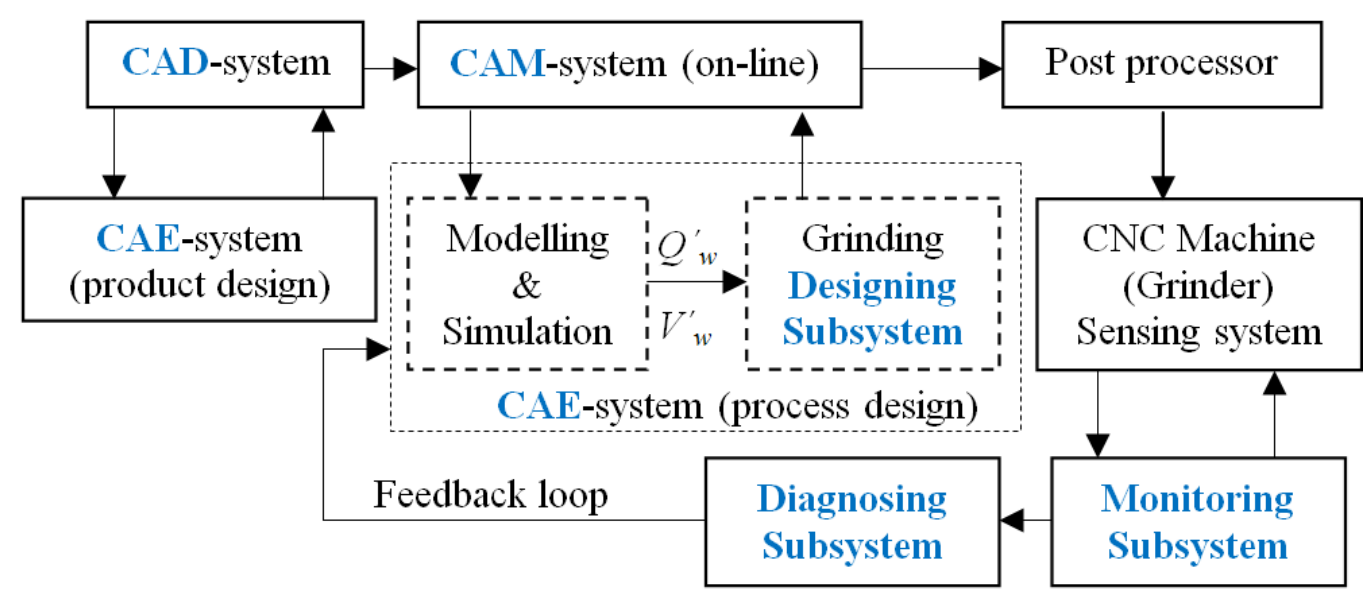

Fig. 4. Integrated CAD/CAM/CAE system shows a novel feedback introduced to implement on-line self-training of the grinding system

Source: [8] 
Such analogy makes it possible to conclude that the educational process (teaching and learning) in a university is also technological one, i.e. contains the appropriate technological operations as well as high technology equipment and production tooling. The latter additionally contains high technology distance learning devices (computer-aided devices) with the special software, namely: Moodle, Google Classroom, Google Meet, Zoom, Skype, Google Suite/Docs as well as WhatsApp, Viber, Telegram, etc.

The purpose of the study is to find an analogy between educational and manufacturing processes based on unified "technological approach", which can be applied for distance learning under the COVID-19 pandemic. Development and analysis of the hierarchical structure of the relevant "control programs" are the tasks of the study.

Essence of the study can be explained as follows. In accordance with the Law of Ukraine "On Higher Education" preparation of specialists with higher education is carried out according to the relevant educational or scientific programs [10]. Educational program - in the form of educationalprofessional (EPP), educational-scientific (ESP) or educational-creative (ECP) ones - is a system of educational components at an appropriate level of higher education within a specialty, which determines the requirements for the level of education of persons who can start studying under this program (e.g., EPP), a list of educational disciplines (EDs) and a logical sequence their study, the number of ECTS credits which are necessary for the implementation of this program, as well as expected learning outcomes (competences), which must possess an applicant of appropriate degree of higher education [10].

A university on the basis of the relevant educational program (such as EPP) with each specialty develops a curriculum that defines the list and volume (scope) of EDs in ECTS credits, a sequence of the EDs study, volume and forms of conducting studies (lectures, practices, laboratory works, etc.), schedule of the educational process (course work), forms of current and final control. Thus, within the limits of legislation, a university independently establishes names of EDs. The academic council of a university approves educational programs (e.g., EPP) and a curriculum for each level (bachelor, magister) of higher education and for both specialty and specialization. The latter is registered in Ukrainian National Agency for Higher Education Quality Assurance.
A manufacturing (technological) process has an analogy with the educational (technological) process through both blocks and links (direct and reverse) as well as according to their functional significance. The use of the "technological approach" allows obtaining new conclusions about the connection of categories "information" and "knowledge" (through the engagement between them) and their place in productive technologies of different nature [11]. For this, feedbacks are used (method of iterations) in the direction from the lower levels of hierarchy to the higher levels.

Essence of research can be explained as follows. Information manifests itself in the form of signals that have a material-and-energy form, although information is neither matter nor energy. From the point of view of the objective being achieved, information can be true and false. True information can be useful and useless. Useful information can be more or less productive. In turn, false information is either deliberately false or false due to its high noise level. Information in the narrow sense is a source of data for decision making in the control of an object. Information in a broad sense is a piece of knowledge in learning theory: both in education and in artificial intelligence.

An important role in this production process is played by information, its transformation, acquisition and transmission. An attempt to introduce and separate the flows of information and materials has been made for manufacturing system by K. Hitomi (Fig. 5). Analysis of the information and material flows shows that they have a common block (product manufacturing stage), which affects both of these flows and is a confirmation of their continuity [4] (this block is shaded in Fig.5). In addition, it can be seen that the structural diagrams of these flows characterize individual aspects (information and material ones) of the product life cycle.

The movement of information and materials in a production system is accompanied by their corresponding transformations, which can be called processing.

Materials processing is a sequence of operations (physical, chemical and/or mechanical actions), which are accompanied by a change in their qualitative state, namely shape, size, structure, etc. Examples of such operations are technological operations of manufacturing products (machining, assembling). A characteristic feature of materials processing is a significant consumption of resources (materials, energy). Materials processing is the base of physical technologies. 


\begin{tabular}{|c|c|c|}
\hline Demand order information & \multirow{2}{*}{$\begin{array}{l}\text { Production } \\
\text { technical } \\
\text { information }\end{array}$} & Raw materials suppliers \\
\hline 1. Aggregate production planning & & Procurement \\
\hline Production plan information & \multirow{2}{*}{$\begin{array}{l}\text { 2. Production } \\
\text { process } \\
\text { planning }\end{array}$} & Raw materials \\
\hline 3. Production scheduling & & Production (in plant) \\
\hline Production scheduling information & \multirow{2}{*}{$\begin{array}{l}\text { Production } \\
\text { process } \\
\text { information }\end{array}$} & Products \\
\hline 4. Production implementation (plant) & & Distribution \\
\hline Production result data & \multirow{3}{*}{ 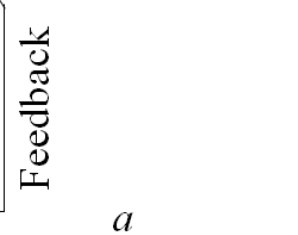 } & Commodities (market) \\
\hline 5. Production control & & Sales \\
\hline Production control information & & Consumers \\
\hline
\end{tabular}

\section{Fig. 5. Flows of information (a) and materials (b) in manufacturing systems with planning stage $(1,2,3)$, implementation stage (4), and control stage (5) [4] Source: [4]}

Information processing is a sequence of mathematical (abstract, symbolic, algorithmic, linguistic, semantic, etc.) operations performed according to some formal rules based on algorithmic procedures.

A characteristic feature of information processing operations is an insignificant (compared to material processing) energy consumption. The energy consumed, for example, by a computer, is many times less than the energy consumed by the electric motors of a metal-cutting machine. Information processing is the base of virtual technology.

\section{CONCLUSIONS}

1. It is shown that the linguistic meaning of information and information processes is one of the important aspects that must be taken into account when studying virtual reality and artificial intelligence. When studying the linguistic meaning of information, it is necessary to use the following terms, which can compose a minimum glossary on the issue under study: artificial intelligence (AI), virtual reality (VR), augmented reality (AR), present (noun), represent (verb), representation (noun), a priori - a posteriori, pre-empirical - post-empirical, pre-production - production - reproduction - postproduction, quality control, measure (noun, verb) measurement (noun) - metrology, modelling - simulation, information and its meaning, ontological information, virtual technologies - physical technologies, reversible (information, virtual) and irreversible (material, physical) processes, game theory - operations research, labor intensity (laboriousness) - cost, optimization (procedure), epistemology (theory of knowledge) - cognition, certainty and uncertainty in science, sustainable development, education - teaching - training, etc.

2. The virtual reality is secondary, based on previous knowledge and corresponds to category "representation". Its development and improvement along the path of progress is possible only when receiving new information that arises from the physical technologies of online product manufacturing. Consequently, an integrated manufacturing system, including CAD/CAM/CAE system can have progress and sustainable development provided the physical technologies for the product manufacture are implementing as a matter of fact and there is a possibility to obtain and use for control the information being arisen.

3. A similar conclusion about the progress of development can be made in relation to the sustainable development of the modern system of higher education and to that part of it called distance learning. As a temporary measure for the period of a pandemic, distance learning is possible and even necessary, however, it is only possible to preserve existing knowledge, since the transfer of knowledge from teacher to student during distance learning is carried out only in virtual reality mode, i.e. corresponds to category "representation" (transmission of available information). However, information itself is not yet 
education. This is a necessary, but not a sufficient condition for successful training and acquisition of relevant competencies. At the same time, the use of augmented reality technologies in the design of educational materials is a profitable acquisition for distance learning.

4. "Technological approach" is proposed for analyzing the educational and manufacturing technological process to find the methods for improving distance learning under the COVID-19 pandemic.

5. It has been established that the necessary conversion condition along the chain of "information - understanding - knowledge (totality of facts) - skills" is the engagement between the com- ponents of this chain based on not only virtual, but also the newly emerging information coming through the feedbacks in the direction from the lower levels of hierarchy to the higher levels.

\section{ACKNOWLEDGMENTS}

This work was carried out in accordance with the state (Ukraine) budget theme of the Odessa National Polytechnic University (2018 - 2021, registration code: 0118U004400) and was supported by the Project of the Structural Funds of the EU, ITMS code: 26220220103.

\section{REFERENCES}

1. Larshin, V., Lishchenko, N., Lysyi, O. \& Uminsky, S. "Intelligent Numerical Control of Profile Grinding". V. Ivanov et al. (Eds.): DSMIE 2021. Lecture Notes in Mechanical Engineering. 2021. p. 203212. DOI: https://doi.org/10.1007/978-3-030-77719-7_21.

2. Lishchenko, N., Larshin, V. \& Marchuk, I. "Solid Lubricants Used in Small Diameter Drilling". V. Tonkonogyi et al. (Eds.): InterPartner 2020. Lecture Notes in Mechanical Engineering. 2021. p. 402-411. DOI: https://doi.org/10.1007/978-3-030-68014-5_40.

3. Larshin, V. P. "Meaning of Information in Virtual and Physical Technologies". Computer Games and Multimedia as an Innovative Approach to Communication. Materials of the All-Ukrainian Scientific and Technical Conference of young Scientists, Postgraduates and Students. ONAFT Publishing House. Odesa: Ukraine. March 25-26, 2021. p. 77-79.

4 Hitoni, K. "Strategic Integrated Manufacturing Systems: the Concept and Structures". International Journal of Production Economics". 1991; Vol. 25 No.1-3: 5-12. DOI: https://doi.org/10.1016/09255273(91)90125-D.

5. Wang, W. "Difference between the Real World and Virtual World". Proceedings. Jun., 2020; Vol.47 No.1: 35 p. [Online]. DOI: http://dx.doi.org/10.3390/proceedings2020047035.

6. Lerner, V. S. "Reality, Information, and Information Observer". Proceedings. May, 2020; Vol.47 No. 1: 10 p. [Online]. Available from: http://dx.doi.org/10.3390/proceedings2020047010.

7. Lishchenko, N. \& Larshin, V. "Gear-Grinding Temperature Modeling and Simulation". Proceedings of the 5th International Conference on Industrial Engineering (ICIE 2019). Lecture Notes in Mechanical Engineering. Publ. Springer. Cham. 2020. p. 289-297. Available from: https://doi.org/10.1007/978-3-03022063-1_32.

8. Larshin, V. \& Lishchenko, N. "Technological Processes and Systems Automation Principles". Towards Industry 4.0: Information Technology, Modeling, Artificial Intelligence and Automation. Monograph: the author's team: V. B. Artemenko, L. V. Artemenko, O. V. Artemenko [et al.]; edited by S. V. Kotlik. Odesa: Ukraine. AstroPrint Publ. 2021. p. 121-131.

9. Larshin, V. P. \& Lishchenko, N. V. "Collation of Educational and Manufacturing Processes". State, Achievements and Prospects of Information Systems and Technology. Proceedings of the XXI all-Ukrainian Scientific and Technical Conference of Young Scientists, Postgraduates and Students. ONAFT Publishing House. Odesa: Ukraine. April 22-23, 2021. 2021. p. 81-82.

10. "On Providing Explanations Regarding Educational Programs". Letter of the Ministry of Education and Science No. 1/9-377 dated 05.06.18 [Online]. Available from: https://osvita.ua/legislation/Vishya_osvita/61021/.

11. Larshin, V. P. \& Lishchenko, N. V. "Educational Technology Information Support". Herald of Advanced Information Technology. Publ. Nauka i Tekhnika. 2019; Vol.2 No.4: 317-327. DOI: http://dx.doi.org/10.15276/hait.04.2019.8. 
12. Levanov, I., Doykin, A., Zadorozhnaya, E. \& Novikov, R. "Investigation Antiwar Properties of Lubricants with the Geo-Modifiers of Friction”. Tribology in Industry 2017; Vol. 39 No.3: 302-306.

13. Duradji, V., Kaputkin, D. \& Duradji, A. "Tribological Studies of Antiwear Antifriction Composition and its Application". Tribology in Industry. 2016; Vol. 38 No.4: 496-507.

14. Xu, Y., Gao, F., Zhang, B., Nan, F. \& Xu, B.-S. "Technology of Self-Repairing and Reinforcement of Metal worn Surface". Advances in Manufacturing 2013; Vol.1: 102-105.

15. Sharma, S. \& Anand, A. "Solid Lubrication in Iron Based Materials - A Review". Tribology in Industry. 2016; Vol. 38 No.3: 318-331.

16. Larshin, V. \& Lishchenko, N. “Adaptive Profile Gear Grinding Boosts Productivity of this Operation on the CNC Machine Tools". Lecture Notes in Mechanical Engineering. 2019. p. 79-88.

17. Lishchenko, N. \& Larshin, V. "Temperature Field Analysis in Grinding”. Lecture Notes in Mechanical Engineering. 2020. p. 199-208.

18. Singh, P., Dureja, J. S., Singh, H. \& Bhatti, M. S. "Nanofluid-Based Minimum Quantity Lubrication (MQL) Face Milling of Inconel 625". International Journal of Automotive and Mechanical Engineering. 2019; Vol. 16 No.34: 6874-6888.

19. Gupta, M. K. \& Sood, P.K. "Surface Roughness Measurements in NFMQL Assisted Turning of Titanium Alloys: An Optimisation Approach”. Friction. 2017; Vol. 5 No.2: 155-170.

20. Hebab, H., Darras, B. \& Kishawy, H. A. "Sustainability Assessment of Machining with NanoCutting Fluids. Procedia Manufacturing. 2018; Vol.26: 245-254.

21. Novikov, V., Gostev, Y., Zaslavskiy, R., Skobeltsin, A. \& Buyanovskiy, I. "Antifriction and Antiwear Resource Restoring Lubricant Composition (ARRC)" (In Russian). In: Proceedings of the ScientificPractical Conference-Exhibition 'Tribotech 2003'. 17.

22. Zhi Min Bai, Na Yang, Man Guo \& Shuo Li. "Antigorite: Mineralogical Characterization and Friction Performances". Tribology International. 2016; Vol.101: 115-121.

23. Krishna, P. Vamsi, Srikant, R. R \& Rao D. Nageswara. "Solid Lubricants in Machining". Proc. IMechE J. Engineering Tribology. 2011; Vol. 225 Part J: 213-227.

24. Suresh Kumar Reddy, N. \& Venkateswara Rao, P. "Experimental Investigation to Study the Effect of Solid Lubricants on Cutting Forces and Surface Quality in End Milling”. International Journal of Machine Tools \& Manufacture. 2006; Vol.46: 189-198.

25. Anand, A., Vohra, K., Ul Haq, M., Raina, A. \& Wani, M. "Tribological Considerations of Cutting Fluids in Machining Environment: A Review". Tribology in Industry. 2016; Vol.38 No. 4: 463-474.

26. Astakhov, V. P. \& Joksch, S. "Metalworking Fluids (Mwfs) for Cutting and Grinding: Fundamentals and Recent Advances". Woodhead Publishing, Cambridge. UK: Philadelphia, PA. 2012.

27. Freeman, Herbert. "Discrete-Time Systems: An Introduction to the Theory". Publ: J. Wiley. New York: $1965.241 \mathrm{p}$.

28. Tönshoff, H. K., Friemuth, T. \& Becker, J. C. "Process Monitoring in Grinding”. CIRP Annals Manufacturing Technology. 2002; Vol. 51 Issue 2: 551-571.

29. Klocke Fritz. "Manufacturing Processes 2: Grinding, Honing and Lapping". Publ. Springer. Berlin: 2009. $433 \mathrm{p}$.

30. Lima, P. U. \&, Saridis G. N. "Design of Intelligent Control Systems Based on Hierarchical Stochastic Automata". World Scientific Publishing Co. Pte. Ltd. Singapore: 1996. 155 p.

31. Lishchenko, N. \& Larshin, V. "Profile Gear Grinding Temperature Determination". In: 4th International Conference on Industrial Engineering, ICIE and Lecture Notes in Mechanical Engineering. Publ. Springer, 2019. p. 1723-1730.

32. Lishchenko, N. \& Larshin, V. "Grinding Temperature Model Simplification for the Operation Information Support System". Scientific Journal Herald of Advanced Information Technology. Publ. Nauka $i$ Tekhnika. 2019; Vol.2 No. 3: 197-205. DOI: https://doi.org/10.15276/hait.03.2019.3.

33. Lishchenko, N. \& Larshin, V. "Temperature Models for Grinding System State Monitoring". Applied Aspects of Information Technology. Publ. Nauka i Tekhnika. 2019; Vol. 2 No. 3: 216-229. DOI: https://doi.org/10.15276/aait.03.2019.4. 
34. Larshin, V. \& Lishchenko, N. "Intermittent Grinding Temperature Modeling for Grinding System State Monitoring”. Applied Aspects of Information Technology. Publ. Nauka i Tekhnika. 2020; Vol. 3 No. 2: 58-73. DOI: https://doi.org/10.15276/aait.02.2020.4.

35. Larshin, V., Lishchenko, N. "Educational Technology Information Support". Herald of Advanced Information Technology. Publ. Nauka i Tekhnika. 2019; Vol. 2 No. 4: 317-327. DOI: https://doi.org/ 10.15276/hait.04.2019.8.

36. Larshin, V. P., Lishchenko, N. V., Babiychuk, O. B. \& Pitel' Ján. "Virtual Reality and Real Measurements in Physical Technology". Applied Aspects of Information Technology. Publ. Nauka i Tekhnika. 2021; Vol.4 No.1: 24-36. DOI: https://doi.org/10.15276/aait.01.2021.2.

Conflicts of Interest: the authors declare no conflict of interest

$\begin{array}{lcl}\text { Received } & 07.12 .2020 \\ \text { Received after revision } \quad 26.02 .2021 \\ \text { Accepted } & 17.03 .2021\end{array}$

\title{
DOI: https://doi.org/10.15276/hait.02.2021.1 \\ УДК $004.942+621.923$
}

\section{ІНФОРМАЦЙНА ПІДТРИМКА АВТОМАТИЗОВАНОГО ПРОЕКТУВАННЯ ТА ВИРОБНИЦТВА}

\author{
Василь Петрович Ларшин ${ }^{1)}$ \\ ORCID: https://orcid.org/0000-0001-7536-3859; vasilylarshin@gmail.com

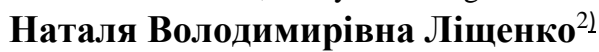 \\ ORCID: https://orcid.org/0000-0002-4110-1321;odeslnv@gmail.com \\ Ольга Борисівна Бабійчук ${ }^{1)}$ \\ ORCID: https://orcid.org/0000-0002-0623-265X; obbabiychuk@ukr.net \\ Ян Питель ${ }^{3)}$ \\ ORCID: https://orcid.org/0000-0003-1942-0438; jan.pitel@tuke.sk \\ 1) Одеський національний політехнічний університет, пр. Шевченка, 1. Одеса, Україна, 65044 \\ 2) Одеська національна академія харчових технологій, вул. Канатна, 112. Одеса, Україна, 65039 \\ 3) Технічний університет в Кошице, Баерова 1. Прешов, 08001, Словацька Республіка
}

\begin{abstract}
АНОТАЦІЯ
Інформаційна підтримка сучасного автоматизованого проектування продуктів та процесів розглядається у цьому огляді відповідно до методології інтегрованої системи CAD/CAM/CAE. Розглянуто три рівні ієрархії управління на етапах проектування та виробництва. На верхньому (організаційному) рівні виконується автоматизоване проектування конструкції продукту та технології його виготовлення. На середньому (координаційному) рівні виконується прив'язка до існуючого технологічного обладнання та налагодження окремих фрагментів програми управління. На нижньому (виконавчому) рівні остаточно створюється, налагоджується та виконується програма управління. Відмінною рисою запропонованої методології автоматизації на етапах проектування та виробництва $€$ використання зворотного зв'язку від нижчого рівня до середнього та вищого рівнів для корекції прийнятих там рішень з урахуванням існуючих управлінських повноважень на цих рівнях ієрархії. Таким чином, зазначені рівні ієрархії інтелектуальної системи відповідають ієрархії об'єктів та суб'єктів управління та контролю з урахуванням повноважень (та можливостей) управління та контролю на кожному рівні. Інформація $є$ основною категорією не тільки в інформаційних (віртуальних) технологіях ії перетворення та передачі, але і у фізичних технологіях матеріального виробництва при виготовленні відповідного матеріального продукту. Такі технології, як правило, містять підготовчий (перед виробничий) та виконавчий (впровадження) етапи. На підготовчому етапі створюється віртуальний продукт (інформаційна модель реального продукту у вигляді віртуальної реальності), а на виконавчому етапі з'являється реальний (фізичний) продукт, що має споживчу вартість (корисність володіння). Це дослідження описує особливості обробки інформації на обох етапах виробництва з метою підвищення іiі ефективності.

Ключові слова: Інформаційні технології; автоматизація; дизайн продукту; дизайн процесів; цифрова модель; CAD/CAM /CAE; програма управління; зворотній зв'язок; рідина для металообробки; тверде мастило; ріжучий інструмент; система шліфування; виробничі потоки; інтелектуальне управління
\end{abstract}




\section{ABOUT THE AUTHORS}
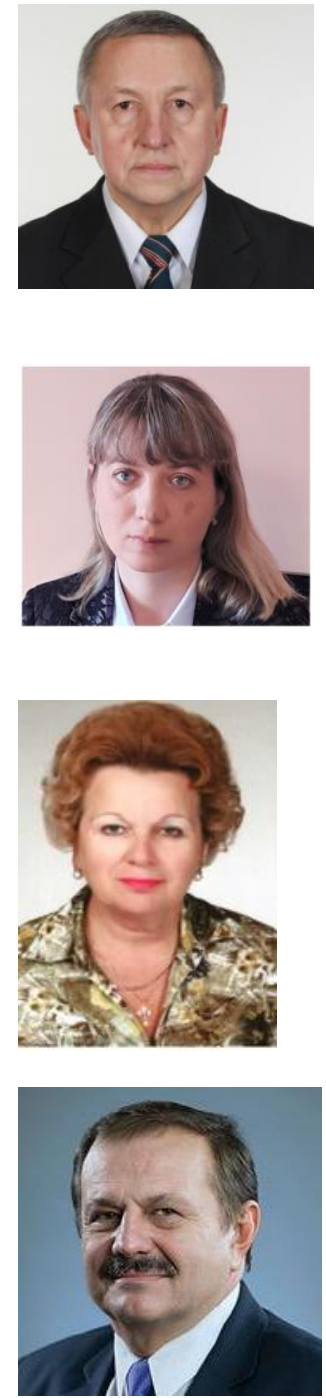

Vasily Petrovich Larshin - Academician of the Ukrainian Academy of Economic Cybernetics (2020). Dr. Sci. (Eng) (1995). PhD (Eng) (1980). Professor of Department of Mechanical Engineering Technology. Odessa National Polytechnic University, 1, Shevchenko Ave. Odesa, 65044, Ukraine ORCID: https://orcid.org/0000-0001-7536-3859; vasilylarshin@gmail.com Research field: Production and Technological Processes Information Ensuring

Василь Петрович Ларшин - академік Української академії економічної кібернетики (2020), доктор технічних наук (1995), кандидат технічних наук (1980), професор кафедри Технології машинобудування. Одеський національний політехнічний університет, пр. Шевченка, 1. Одеса, 65044,Україна

Natalia Vladimirovna Lishchenko - Dr. Sci. (Eng) (2018), PhD (Eng) (2006), Dean of Faculty of Computer Science and Automation, Professor of the Department of Electromechanics, Mechatronics and Engineering Graphics, Odessa National Academy of Food Technology, 112, Kanatna Street. Odesa, 65039, Ukraine

ORCID: https://orcid.org/0000-0002-4110-1321; odeslnv@gmail.com Research field: Information Support of Technological Processes

Наталя Володимирівна Ліщенко - доктор технічних наук (2018), кандидат технічних наук (2006), декан факультету Комп'ютерних систем та автоматизації, професор кафедри Електромеханіки, мехатроніки та інженерної графіки. Одеська національна академія харчових технологій, вул. Канатна, 112. Одеса, 65039, Україна

Olga Borisovna Babiychuk - Senior Lecturer Institute of Computer Systems. Odessa National Polytechnic University, 1, Shevchenko Avenue. Odessa, 65044, Ukraine

ORCID: https://orcid.org/0000-0002-0623-265X; obbabiychuk@ukr.net

Research field: Computer Simulation of Electromechanical Devices

Ольга Борисівна Бабійчук - старший викладач Інституту комп'ютерних систем. Одеський національний політехнічний університет, пр. Шевченка, 1. Одеса, 65044, Україна

Ján Pitel' - Vice-Dean for Development and External Relations, Technical University of Kosice, 1, Bayerova. Prešov, 08001, Slovak Republic

ORCID: https://orcid.org/0000-0003-1942-0438; jan.pitel@tuke.sk

Research field: Automation \& Control Systems; Simulation and Modeling

Ян Пітель - заступник декана з розвитку і зовнішніх зв'язків. Технічний університет Кошице, Баерова 1. Прешов, 08001, Словацька Республіка 